NORDISK MUSEOLOGI $1998 \cdot 2$, S. 17-28

\title{
DEAD OR ALIVE - SOME QUESTIONS ABOUT Objects And PeOple
}

\section{Sally MacDonald}

This paper is about a few objects in two museums I know. One - my last place of work - was what might be called a social history or community history museum in Croydon just outside London. The other - where I have worked for the last six months - is a museum of Egyptian archaeology in a university in central London. In most parts of Britain, archaeology and social history (in the museum context at any rate) are distinct disciplines with their own specialist groups, networks and methods. I am still trying to come to terms with very different types of objects, terminologies and ways of thinking and to work out whether there are approaches I can bring from one environment to the other. I find it challenging to juxtapose objects from the two museums - some of them separated by nearly 5000 years - and to think about the questions and issues they raise for me now.

\section{WHAT IS A GOOD MUSEUM?}

In Croydon I had the opportunity to set up a new museum service almost from scratch. ${ }^{1}$ It was a museum mainly for local people funded by local government and it opened in 1995. Croydon is both a suburb of London and an urban centre in its own right; it has over 300,000 inhabitants of whom around $20 \%$ are of African, Caribbean or Asian origin. The centre of the town is full of skyscrapers and big roads and as a result the people who live there and visit do not connect it with history. In setting up the museum I and my colleagues commissioned qualitative market research to try to ascertain what people might want from a museum there. ${ }^{2}$ We asked non-visitors as well as visitors and one of the remarkable findings was that there was little difference in the way they felt: all groups found museums boring; visitors simply possessed a sense of duty that non-visitors lacked. But once freed to imagine what a good museum might be like they were energised (Fig 1). ${ }^{3}$ It may be that these ideas would not apply elsewhere, but I have used these points, and quotes from Croydon people, as the framework of this paper. 
SALLY MACDONALD

\section{A GOOD MUSEUM}

* changes

$*$ is about me

$*$ takes me out of myself

$*$ is contentious

$*$ is a place to learn

$*$ is bright, funny, inspiring

* is about the future as well as the past

Fig. 1: What a good museum might be like.

The Petrie Museum of Egyptian Archaeology was set up 1913 as a teaching collection for Egyptology students at University College London. It contains mainly items excavated in Egypt by the extraordinary archaeologist William Matthew Flinders Petrie (1853-1942), often described as the founder of scientific archaeology. Petrie excavated in Egypt most years from 1880 to 1925 ; he had to obtain the permission of the Egyptian authorities to dig each site but was thereafter left very much to do as he wished. The finds from each dig were divided: some things were kept in Egypt and what Petrie was allowed to export was then offered to those institutions and individuals who had funded the excavations. He kept for himself a collection of smaller things that illustrated everyday life in Ancient Egypt, the things that no-one else wanted, the things he did not himself understand and therefore wanted to work on. In 1913 University College London bought Petrie's collection and it is today part of the Institute of Archaeology at UCL. Its primary purpose has always been as a teaching and research collection for students but it has enormous potential as a study collection for the general public. Research is still needed into the attitudes of Londoners - particularly those of Egyptians and other Africans - to Egyptian archaeology, but it is clear that the subject of Ancient Egypt has an almost universal appeal.

\section{CAN A MUSEUM BREAK AWAY FROM ITS PAST?}

In Croydon we had very little space but we wanted to make the displays very rich; we decided each object should have a 
Fig 2: Lock of hair belonging to Eva Smith, of Croydon; in the mid 1920s for the first time she had her hair cut into a fashionably short bob. Her daughter lent the hair. to be displayed in Lifetimes.
Fig 3: Woman's hair and section of scalp taken from a tomb in Gurob, 18th or 19th dynasty; $1567-1200$ BC (UC 30139)
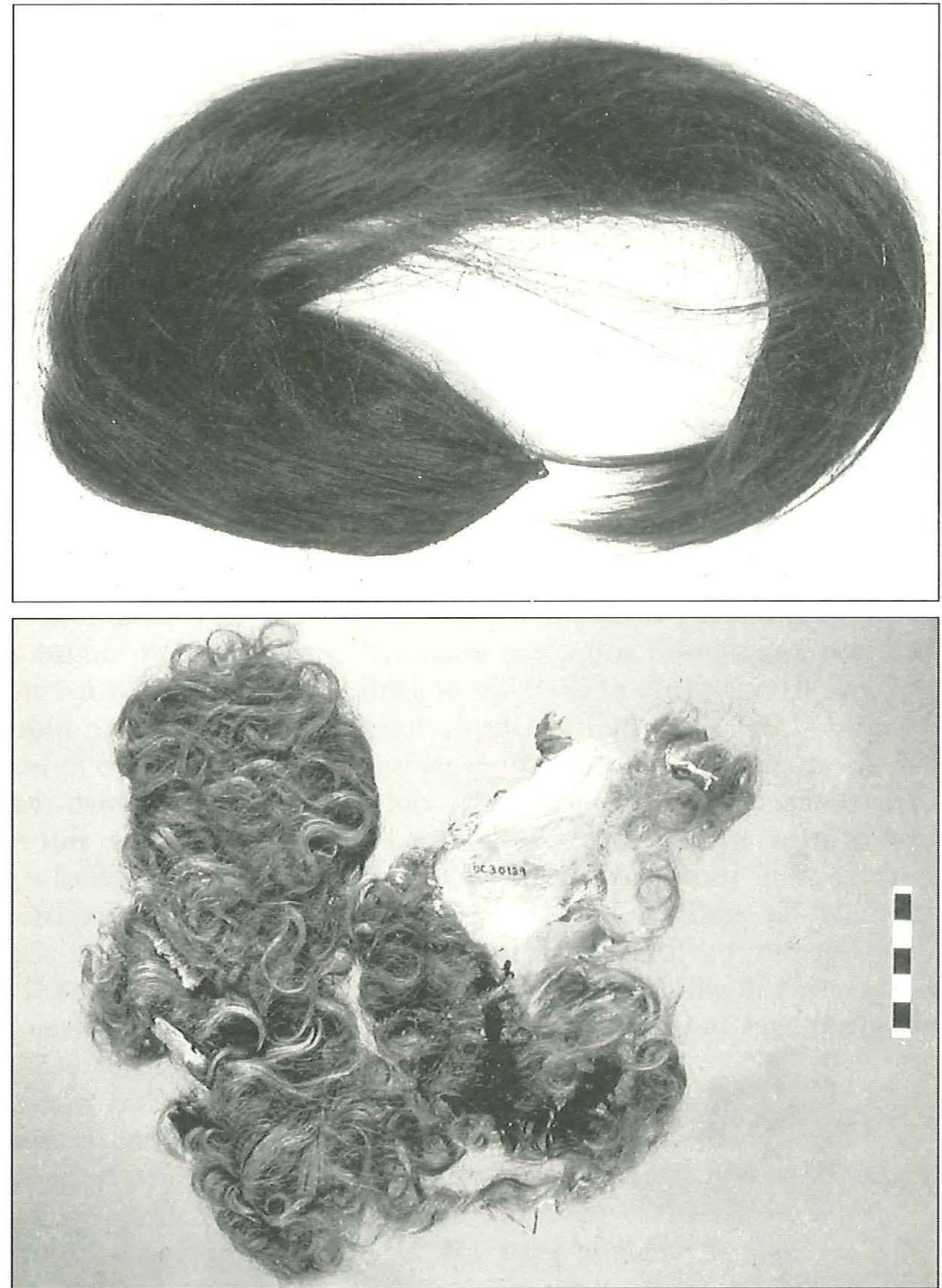

strong local provenance and story. Our method of collecting from people in Croydon was a very personal and intense one $^{4}$; we visited the people who offered us objects, interviewing them on subjects relating to the potential exhibits, borro- wing and copying related photographs, photographing and documenting potential exhibits. In the eventual displays, each object was linked to a story on a multimedia programme in order that it could be presented in a rich context. But the 
20 objects were always the focus; we only ever chose exhibits we felt were meaningful and powerful. One woman, a Mrs Cheetham, lent us a length of hair (Fig 2); in the 1920s her mother (now dead) had her long hair cut for the first time into a fashionably short bob. The hair was precious - it was part, after all, of her mother's body - but because the museum collected in a collaborative and personal way Mrs Cheetham was consulted over all aspects of its display and presentation. She could ensure that her mother's memory was treated with respect.

This courtesy was not afforded to the anonymous woman whose hair is now shown in the Petrie Museum (Fig 3). This hair, and a section of scalp, was excavated by Petrie from a tomb of the 18 th or 19 th Dynasty (1567-1200 BC) at Gurob. Even the most careful, the most organised archaeology is inevitably a kind of violation because it takes place without consent. To date there have been no formal demands for restitution of objects from the collection, but I feel there is a need to look at ways in which things can be shared and given back in other ways.

\section{A GOOD MUSEUM CHANGES}

A museum is only a temporary place. There is not one storehouse in the world that has lasted a couple of thousand years. (W M F Petrie, 1904) ${ }^{5}$

Say every six months you could change the theme (white teenager in Croydon, 1990) ${ }^{6}$

Petrie was an extraordinarily perceptive man and a century later many of his ideas still seem quite radical. For instance, many of my contemporaries believe that museums are permanent institutions, with permanent collections. Petrie had crawled half-naked at night along semi-submerged tunnels inside pyramids thousands of years old. He knew that decay was a natural process and could see museums as a fairly recent phenomenon.

When we interviewed people in Croydon about museums, no-one spoke naturally about preservation: they wanted change and movement. Because of this, and because we were unsure whether the museum would be successful or not, we borrowed rather than acquired objects for the displays. People lent us things for five years after which they had the option to renew or to terminate the loan. One lady lent us a commode that her mother had used in her house in Croydon around 1895. She decided not to renew the loan as she is getting older and would like to use the commode herself now. This concept is very much that of the ecomuseum - it is not new. But many of my museum colleagues still find it shocking. In Britain, in order to be registered, a museum must own or intend to acquire substantial permanent collections. The museum world in general lays far too much emphasis on owning and not nearly enough on sharing or giving. Too many curators still regard the collections as their own. The material excavated by Petrie is now in at least 20 public collections worldwide - there is great potential for re-assembling material from specific sites, now dispersed. Doing this kind of thing will require a substantial shift of attitude and resources. But the alternative is too static, too dull, too wasteful. 


\section{A GOOD MUSEUM IS ABOUT ME}

In Croydon we tried to create an inclusive museum, where people of different racial and cultural backgrounds could see themselves represented. Not surprisingly, we found it hard to convince Black and Asian people we were serious about this. The feeling was particularly strong among older people, who had dealt with the racism they encountered in Britain by forming their own self-help groups. They regarded their history as precious and distinct. One organisation that did get involved with the museum was a group called the Guyanese Organisation for Cultural Advancement (GOCA). They made and lent to the museum a banner embroidered with a map of Guyana and scenes from everyday life they remembered from their youth (Fig 4). Joyce Daniels, a member of GOCA, recalled:

We started GOCA in 1976 to improve the education of the children. There was no need for any elderly grouping then. As time went by the children became parents, therefore the elderly contribution as part of an extended family gradually diminished. So the poor old dears were left alone. In the West Indies, people took the pleasure to care for the elderly. It is a different era now, the extended family fabric is going. Some people still try to cope here, with a lot of difficulty I can tell you. So that's how we picked up the elderly club. There are other day centres and pop-ins but they don't feel welcome. And that is why we concentrated on the elderly in the community.?

One Asian group who chose not to get involved instead wanted advice on setting up their own collection of artefacts which they could use to educate young Asians about their culture. Many Black and Asian people were not used to seeing themselves represented positively in museums and did not trust us to do it properly.

If I think back to when I studied Ancient Egypt at school I am sure that noone ever suggested to me that the Egyptians were anything other than white-skinned; Cleopatra was Elizabeth Taylor. It was quite a shock to me when in my late twenties I first encountered people who saw Egyptian history as part of African history; so effective had been the appropriation of Egypt, so inherently racist my education that I had never previously thought of Egypt as part of Africa. And yet the Greek historian Herodotus who was in Egypt in the mid-5th century BC described the Egyptians as «having black skins and woolly hair». ${ }^{8}$ The question of the skin colour of the Ancient Egyptians is complex but even today too few schoolchildren know that some of Egypt's most powerful pharaohs and many ordinary Egyptians were certainly black-skinned (Fig 5). Making this clear to both black and white children in London now might be one way of giving back a stolen history.

Our history? We'd be lost without it (Retired Asian Man, Croydon, 1990) ${ }^{9}$

\section{A GOOD MUSEUM IS CONTENTIOUS}

Questions of ownership and heritage are complex enough when dealing with recent history; they become vastly more difficult when applied across millennia. I have always found the idea of communities and therefore of community museums difficult. Communities are used to define 
SALLY MACDONALD

22

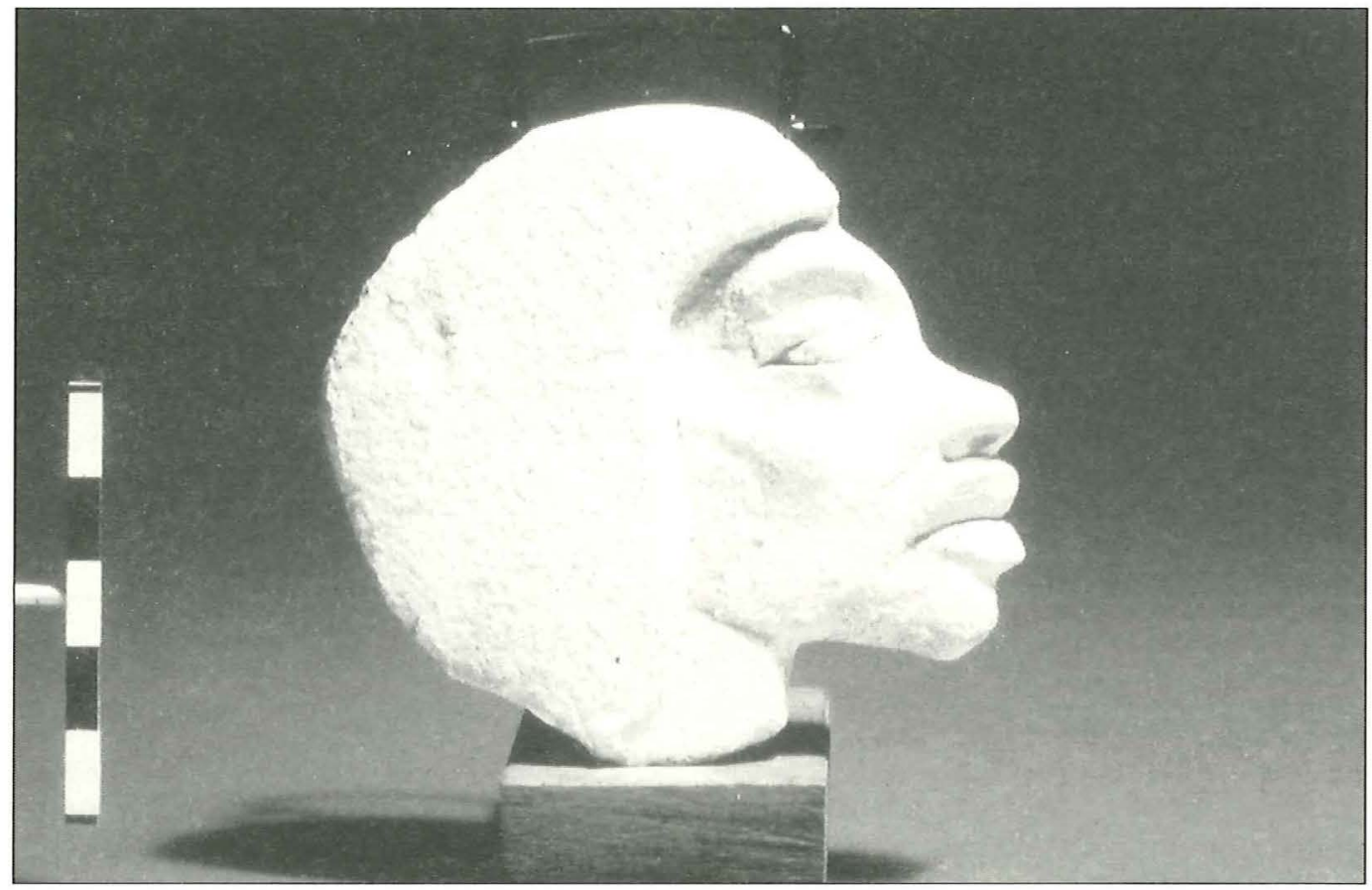

Fig 5: Limestone carving (sculptor's trial piece) of a Black man from Amarna, city of Akhenaten and Nefertiti, 1379-1361 BC. (UC 009)

«them» rather than «us» or «me». People don't fall into neat categories. In Croydon we tried hard to include a representative group of people in our displays but equally we tried to avoid pigeon-holing people or forcing them into rôles. They were individuals with belongings and stories more interesting than any stereotype. Shanaz Aslam, a 13 year old with a British mother and Pakistani father, lent us a woollen shawl or chadder from Pakistan (Fig 6). She said of it:
Even in England at the age of 7 we had to start covering our legs up, especially when our grandmother was around. When we went back to Pakistan when I was 9 it was even more extreme. You are taught that you should have everything covered, otherwise your dignity, your respect is threatened. In the first year I was there I was given the chadder and the chadders just get bigger and bigger as you get older and you cover more of yourself until you're my age when you totally hide yourself. After a while you begin to WANT to cover yourself. You know, it's IN THERE, without anybody ever telling you so. 


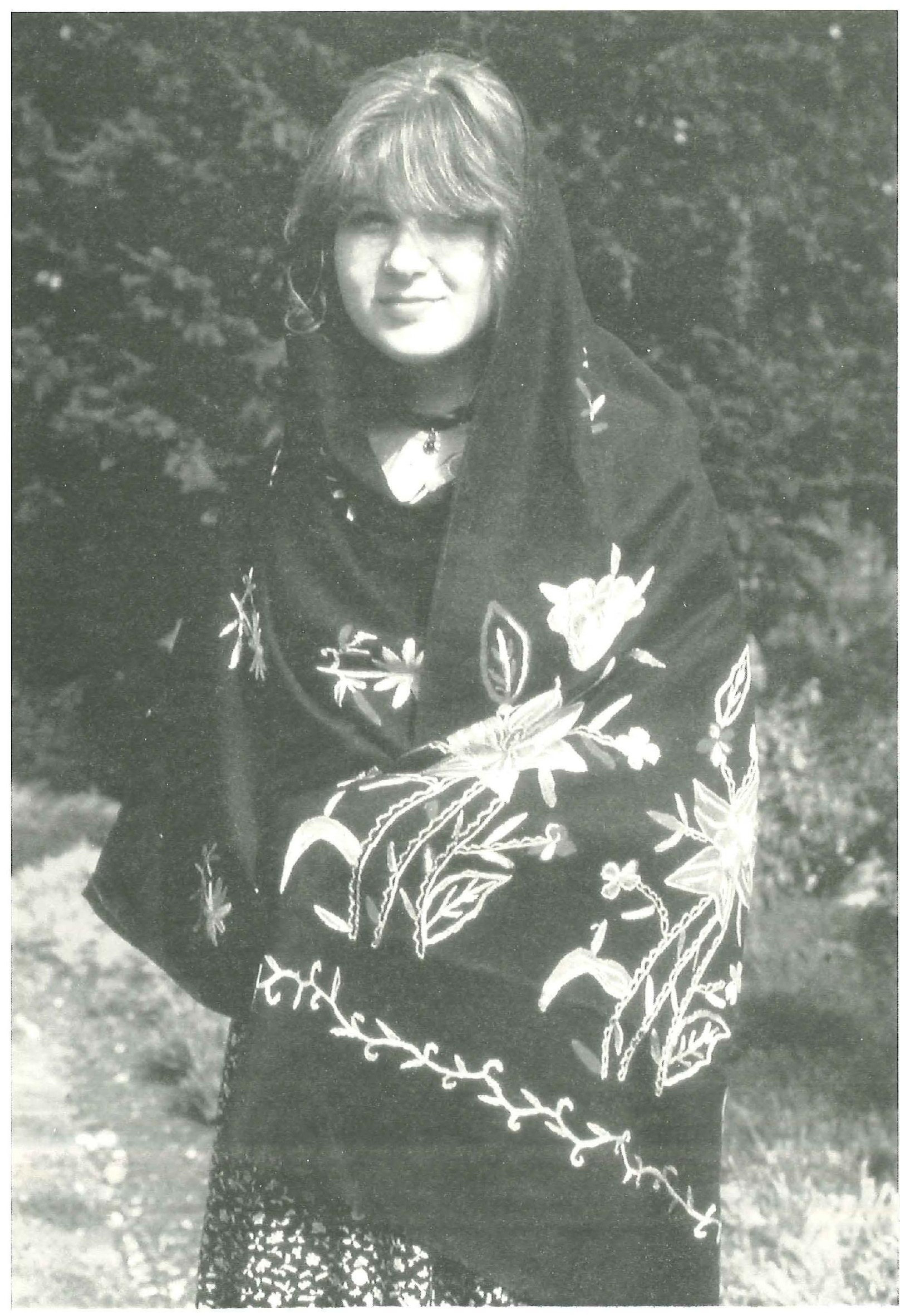


24 Shanaz came back to England when she was 12. I've more or less escaped from the religion. But it's still going to take a while. ${ }^{10}$

It's rare in museums to find children's stories told by children. Normally they are told by adults sentimental for their lost youth and illustrated with depressingly safe objects; toys and games. The Petrie Museum has an erotic dancing dress (Fig 7), made from a net of beads, from Qau in Middle Egypt, which would have been worn by an 8 or 9 year old girl with nothing underneath. The dress is complete with prominent breast caps and nipples, with a fringe of shells plugged to rattle when the girl moved. At a time when child sexuality and paedophilia are taboo subjects this dress seems to cause problems for many visitors. It is particularly problematic to try to interpret it for an Egyptian Muslim child in London today.

History is not a pretty thing (Black Retired Man, Croydon 1990) ${ }^{11}$

\section{A GOOD MUSEUM TAKES ME OUT OF MYSELF}

Setting up the museum in Croydon we were not starting entirely from scratch. We found some objects which had, in the absence of a local museum, been given to the local studies library. One of these was an early 20 th century parasol which appeared, from a letter on the files, to have been given to the library by two sisters from Croydon. They had left the area decades ago but we managed to find one of them, Dorothy Farr, by now an elderly lady living in Wolverhampton. We interviewed her about the parasol and the memories it triggered for her. They were memories of her childhood of her child- hood, from around 1910. She was one of seven sisters. She recalls:

We always went away for a fortnight at the end of July. Always somewhere nearby like Littlehampton. We always used to have very nice holidays and father always used to put himself out. We younger ones generally didn't see our father at any other time. We were always up in our rooms by 6 o'clock in the evening and father came back at 7. And he didn't get home until 2 o'clock on a Saturday and then he and mother slept all afternoon. On Sunday they went to church early. We all had to go at 11 o'clock and father stayed and did the gardening. Then they used to sleep all afternoon and go to church in the evening and we had to go to bed. But on holidays we'd go for long walks together and we'd play cricket and ball and fly kites. Oh I used to love flying kites. We used to have lovely walks across the sand dunes and look for shells. Father was very nice.

The parasol had been her mother's idea to keep the girls looking fair.

Mother was quite strict. She liked us to be little bits of her really, be ladylike. You always had to do exactly as she said. ${ }^{12}$

Without that contact with a living person the parasol might have had a label that read, "Sunshade, belonging to the Farr family of Thornton Heath, about 1910». Behind that particular sunshade there's a whole story about how this little girl got on with her parents. Using oral history and contemporary comment is very common now in social history museums. Clearly one can't engage with the dead in the same way, but there are many ways in which living people can bring ancient things alive. In the Petrie Museum is a cyl- 
Dead or Alive - Some Questions about Objects and People

indrical pottery object with holes in the sides (UC 16773). One end is solid, the other end is missing. It was excavated by Petrie in the town of Kahun which was a pyramid builders' town inhabited for nineteen years only (1897 - 1878 BC) by workers building the pyramid of King Senusret II. When the pyramid was complete the town was deserted and (unlike the pyramids, tombs and temples) was not thought worth robbing. Petrie found this object in the town rubbish dump. $\mathrm{He}$ thought it was a chicken coop. Someone recently travelling in North Africa saw a very similar object still in use - it was a rat-trap. A replica has now been made and the object can be understood in a new context; Petrie had noticed evidence of rats in the holes in the walls of the workers' housing. While many aspects of life change beyond recognition in only a few decades, others survive; in this case for nearly 4000 years. People explain things and things explain people.

What is it that underlies our fascination with the past?...It is the love of life (W M F Petrie, 1904) $)^{13}$

\section{A GOOD MUSEUM IS A PLACE TO LEARN}

The Petrie Museum has very few visitors for a central London museum with highly appealing subject matter. But it has a tradition of access and hands-on study that most museums lack. It was set up as a teaching collection and it is expected that visitors will need to hold, to draw, to pho-

Fig 7: Girl's bead-net dancing dress excavated in Qau in Middle Egypt, 2400 BC (UC 17743).

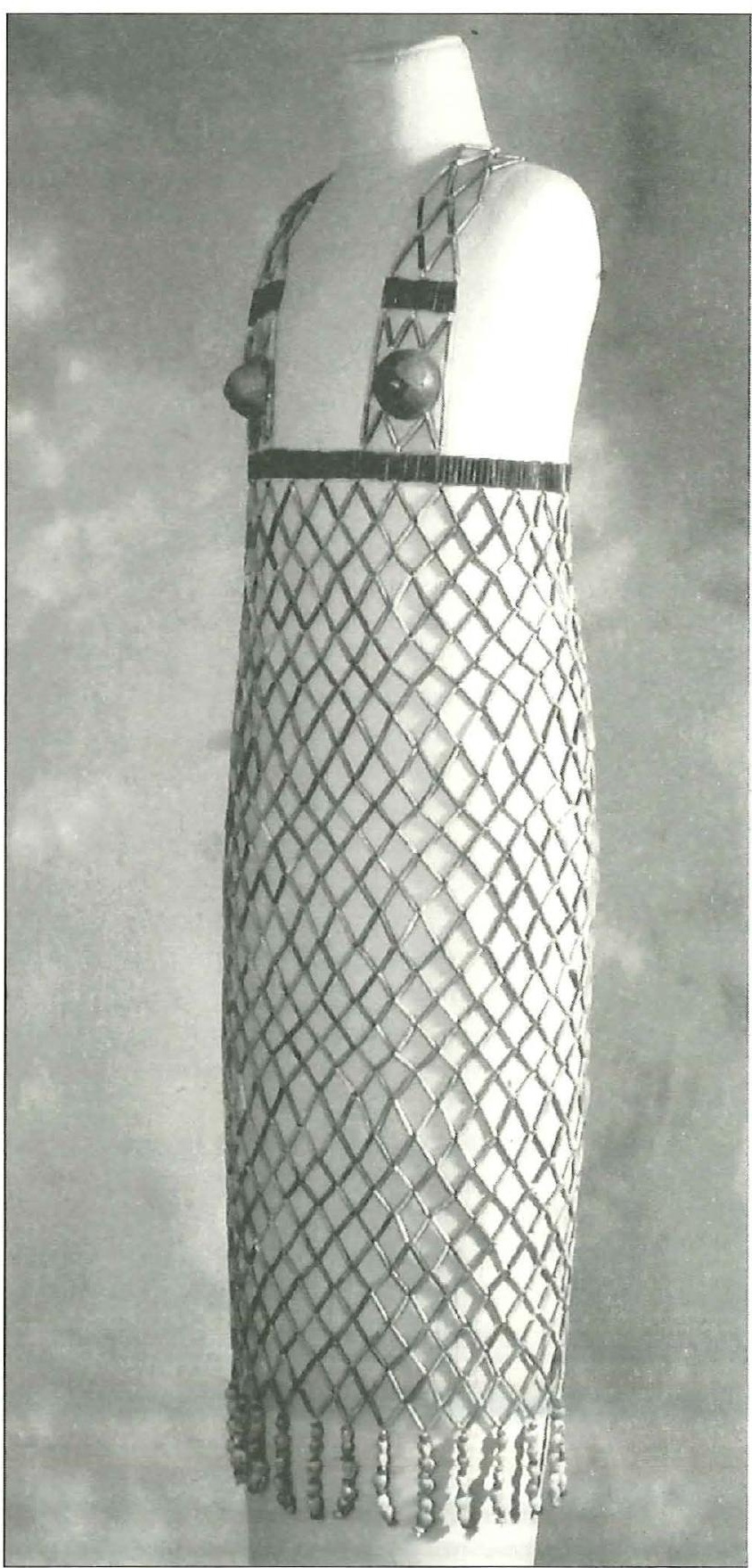


tograph objects. Catalogues, stores and displays are in the same area so researchers can see and study anything they wish to by appointment. Analysis, including destructive analysis, is accepted as a means of study and regularly takes place. The collections are there to be not just visited but used. Researchers working at the Petrie have analysed anything from ancient bread loaves, the pigments used in faience, the contents of jars.

This should be an exciting cyclical process in which information is taken from the objects, assessed, interpreted, and returned to be added to the store of information on which future research may draw. But often it is not. Researchers may forget or omit to send their findings back to the museum at all. And there are problems associated with this academic environment, where original ideas and publications are worth money; whole subjects are sometimes "kept» for individuals who may never deliver the goods. Academics earn more points for publishing in peerrefereed journals than they do from producing popular books or TV programmes. Without a financial impetus it can take years for new research to become properly public.

It seems to me that there is great potential for museums to develop in this area by offering real access to the public. English primary schools now have to have a daily "literacy hour" for all pupils but we are not teaching children or adults how to read objects. I think this is because to really read objects you have to be able to touch them and smell them - just looking at them in a case is nothing like the same experience - and museums (like children) are too possessive about their objects to want to share them in this way. But if we can develop proper systems for sharing both the objects and the information that comes from people's contact with them, we have huge potential for increasing research and understanding and for developing skills.

Every fragment of the products of the past is concrete history (W M F Petrie, 1893) ${ }^{14}$

That's the whole idea of museums, you should investigate and discover (Family Museum Goer, Croydon, 1990) ${ }^{15}$

Our museums are ghastly charnel houses of murdered evidence (W M F Petrie, 1904) ${ }^{16}$

\section{A GOOD MUSEUM IS BRIGHT, FUNNY, INSPIRING}

As a museum professional, as someone who is skilled in reading objects, it is very hard to accept that others may not find them appealing. In Croydon we carried out research to see how visitors used the displays; which exhibits attracted them and held their attention. The early (pre 1918) displays were the hardest for most of our visitors, partly because they contained less familiar objects but also because they were less colourful, more old. These things are an acquired taste. There was no doubt about which object people liked best; it was a red "bubble car", made by a Croydon firm in the early 1960s. It is bright, cheeky, shiny, round, tactile. The bubble car equivalent in an archaeological museum would have to be something big and gold, which stands out from the mass of small brown things that constitute the main body of the collection. A recent (and unusually honest) visitor to the Petrie Museum just looked around, sighed with tiredness and said to me, "If only it was a 
bit more colourful». Especially where objects cannot be handled, giving them visual appeal and richness - whether through lighting, props or other means of backgound colour - is really important.

You've got to have fantasy if you want people to go (Family Museum Goer, Croydon, $1990)^{17}$

\section{A GOOD MUSEUM IS ABOUT THE FUTURE AS WELL AS THE PAST}

Museums are boring - they should have the future (Asian Teenager, Croydon, 1990) ${ }^{18}$

I want to end by mentioning the future - which is something most museums deal with very badly or not at all. Most of the things excavated in Egypt were in some way intended as a message to the future. Usually (when dealing with tombs and temples) these were messages to the gods, since intercepted by humans. One of my favourite museum objects ever is a small, brown and distinctly unappealing-looking wooden plank found in Croydon during the refurbishment, in 1994, of the town hall, which had been built a century earlier. It was found during the demolition of a staircase in the basement - it had been used as part of the shuttering into which concrete had been poured - and had obviously been put there by a builder for future builders to find. On one side is inscribed,

This town hall in Croydon is the first Society job that was ever built in Croydon and may it not be the last Amen.

The town hall was built with money put up by a new building society called The Liberator, set up by Croydon's first mayor, Jabez Balfour. Many people put their savings into the society which was from the start a corrupt and fraudulent organisation. In 1892 the society collapsed, many ordinary Croydon people losing their life savings. Balfour escaped but was caught and sentenced to 14 years' hard labour. On back of the plank it says,

This bloody thief J Balfour is now in the court in London May 1895. And fuck them all.

The builders that found this piece of wood were so intrigued by the use of the word "fuck" that they came to museum staff to ask about it. This unofficial and irreverent message spoke directly from builder to builder across a century. Museums talk about their mission to preserve material evidence in such a clinical way, but rarely think about what this means, that museums should be messages to the future; potent, troubling, funny. My message is: work out what your message is and rediscover the magic of burial and discovery.

\section{FOOTNOTES}

1. MacDonald, S, 1998. Croydon - What History?, in Making City Histories in Museums, London: Routledge (forthcoming).

2. MacDonald, S, 1992. Your place or Mine? Are Museums Just for People Like Us?, Social History

Curators Journal, volume 19, pp21-27.

3. This summary is distilled from three separate pieces of research: Croydon College, 1990. Market Research for Croydon Museum, unpublished; Fisher, S, 1990. Bringing History and the Arts to a New Audience: Qualitative Research for the London Borough of Croydon, unpublished; Fisher, S, 1993. Qualitative Research to Determine 
an Exhibitions Programme for Croydon Museum Service, 1993 unpublished. Copies of these reports may be obtained from Croydon Museum Service.

4. Fussell, A, 1992. Politics with a small "p»: Collecting with that personal touch, Conference Paper, The Politics of Collecting, Walsall, unpublished. Fussel, A, 1997. Make 'em laugh, make 'em cry'. Collecting for Lifetimes, - the interactive museum about Croydon people. Nordisk Museologi 1997/1 p 39-56.

5. Petrie, W M F, 1904. Methods and Aims in Archaeology, London: Macmillan, p180.

6. Fisher, S, 1990, op cit.

7. Lifetimes multimedia displays, 1995.

8. Herodotus, The Histories, Book 2, about 430 BC, translated by Aubrey de Selincourt, London, Penguin (revised 1996) p121.

9. Fisher, S, 1990, op cit.

10. Lifetimes multimedia displays, 1995.

11. Fisher, S, 1990, op cit.

12. Lifetimes multimedia displays 1995.

13. Petrie, W M F, 1904. op cit, p192.

14. Petrie, W M F, 1904, op cit, p81.

15. S Fisher 1990, op cit.

16. Petrie, W M F, 1893. Introductory Lecture at University College London 14 January 1893 , quoted in Janssen, R, The First 100 Years: Egyptology at University College London $1892-$ 1992, London: University College London, pp98-102.

17. Fisher, S, 1990, op cit.

18. Fisher, S, 1990, op cit.
Sally MacDonald has studied Latin, Archaeology and Ancient History and over the past 15 years held a variety of museum jobs. In 1989 she moved to Croydon to set up a museum service from scratchLifetimes, a museum about Croydon people, an exhibitions and education programme and a heritage service. For six months she has been Manager of the Petrie Museum of Egyptian Archaeology at University College London.

Adr: Petrie Museum, University College London, Gower Street, London WC1E 6BT, UK

Fax: +44-1715042886 